\title{
Identifikasi Zat Aktif Dalam Ekstrak Tanaman, Tes Anti Jamur dan Anti Serangga ${ }^{1}$
}

\author{
Ari Swastikawati \\ Balai Konservasi Borobudur \\ Email: arie_swastik@yahoo.com
}

\begin{abstract}
Abstrak : Indonesia memiliki beraneka ragam warisan budaya, baik dalam bentuk tangible maupun intangible. Salah satu bentuk warisan budaya intangible adalah metode konservasi tradisional. Beberapa metode konservasi tradisional tersebut antara lain penggunaan akar wangi, ratus sebagai bahan fumigant alami dan lain-lain. Metode konservasi tradisional tersebut masih berupa pengetahuan yang bersifat pre-scientific knowledge. Menjadi tugas dan tanggung jawab ahli konservasi untuk mengubahnya menjadi scientific knowledge melalui serangkaian penelitian ilmiah di laboratorium. Pada penelitian dalam pemagangan di laboratorium konservasi NRICH, Korea telah dilakukan identifikasi zat aktif yang terdapat dalam akar wangi. Tujuan khusus penelitian ini adalah menyusun prosedur pengambilan zat aktif dalam akar wangi, mengidentifikasinya, dan mengetes kemampuan ekstrak akar wangi, daun cengkeh dan ratus sebagai anti jamur dan anti serangga.

Analisis laboratorium yang dilaksanakan meliputi identifikasi zat aktif akar wangi (karena keterbatasan waktu identifikasi zat aktif dari cengkeh dan ratus tidak dapat dilaksanakan). Sedangkan eksperimen yang dilaksanakan meliputi tes anti jamur dan anti serangga pada ekstrak akar wangi, daun cengkeh dan ratus. Prosedur dalam identifikasi zat aktif akar wangi terdiri dari ektraksi, penyaringan atau filtrasi, pengumpulan, pemisahan, analisis kromatografi dan nuclear magnetic resonance.

Hasil penelitian belum dapat mengidentifikasi zat aktif dalam akar wangi karena keterbatasan waktu sehingga analisis menggunakan nuclear magnetic resonance tidak dapat dilaksanakan. Hasil tes anti jamur dan anti serangga menunjukan esktrak daun cengkeh memberikan hasil terbaik dalam tes anti-jamur dan anti-serangga diikuti oleh ekstrak ratus kemudian ekstrak akar wangi.
\end{abstract}

\begin{abstract}
Abtract : Indonesia has a diverse cultural heritage, both tangible and intangible forms. One form of intangible cultural heritage is the traditional conservation methods. Some traditional conservation methods include the use of vetiver and ratus as a natural fumigant. Traditional conservation methods are still in the form of knowledge that is pre-scientific knowledge. The duty and responsibility of conservation experts turn it into a scientific knowledge through a series of scientific studies in the laboratory. On research of internship in Conservation Science Laboratory $\mathrm{NRICH}$, Korea has made the identification of the active ingredient contained in vetiver. The specific objective of this study is to develop a decision procedure in the active ingredient of vetiver, identification, and test the ability of extracts of vetiver, clove leave and ratus as an anti-fungal and insecticidal test.

Laboratory analyzes performed include identification of active ingredient of vetiver (due to time constraints identification of active ingredient of clove and ratus unenforceable). While experiments conducted tests include anti-fungal and insecticidal test on vetiver extract, cloves extract and ratus extract. Procedure in the identification of the active ingredient consists of extraction of vetiver, filtration, concentration, separation, chromatographic analysis and nuclear magnetic resonance.

The results have not been able to identify the active ingredient in vetiver because of time constraints that uses nuclear magnetic resonance analysis can't be carried out. The results of the anti-fungal and insecticidal test, clove extract showed the best results in tests of anti-fungal and insecticidal test followed by extract ratus then extract vetiver.
\end{abstract}

\section{PENDAHULUAN}

\section{A. Latar Belakang}

Indonesia memiliki beraneka ragam warisan budaya, baik dalam bentuk tangible maupun intangible. Salah satu warisan budaya yang jarang disinggung adalah kearifan lokal dalam mengkonservasi benda cagar budaya. Metode konservasi tersebut dapat dikategorikan sebagai pre-scientific knowledge. Pre-scientifik knowledge adalah ilmu pengetahuan yang ada dalam masyarakat dalam bentuk mitos, tradisi, yang diturunkan dari satu generasi ke generasi berikutnya dan dikomunikasikan dalam bahasa lisan.

Menjadi tugas dan tanggung jawab para ahli konservasi untuk mengubah ilmu pengetahuan yang masih bersifat pre-scientific knowledge menjadi scientific knowledge melalui 


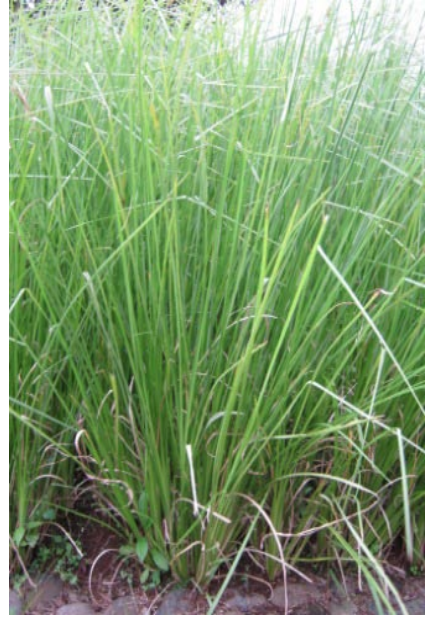

Gambar 1. Rumput penghasil akar wangi

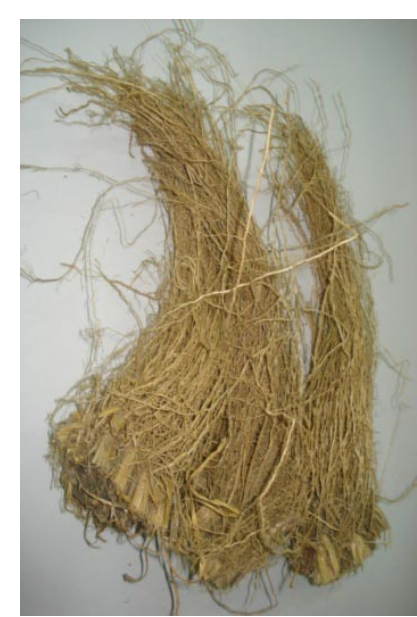

Gambar 2. Akar wangi yang sudah kering

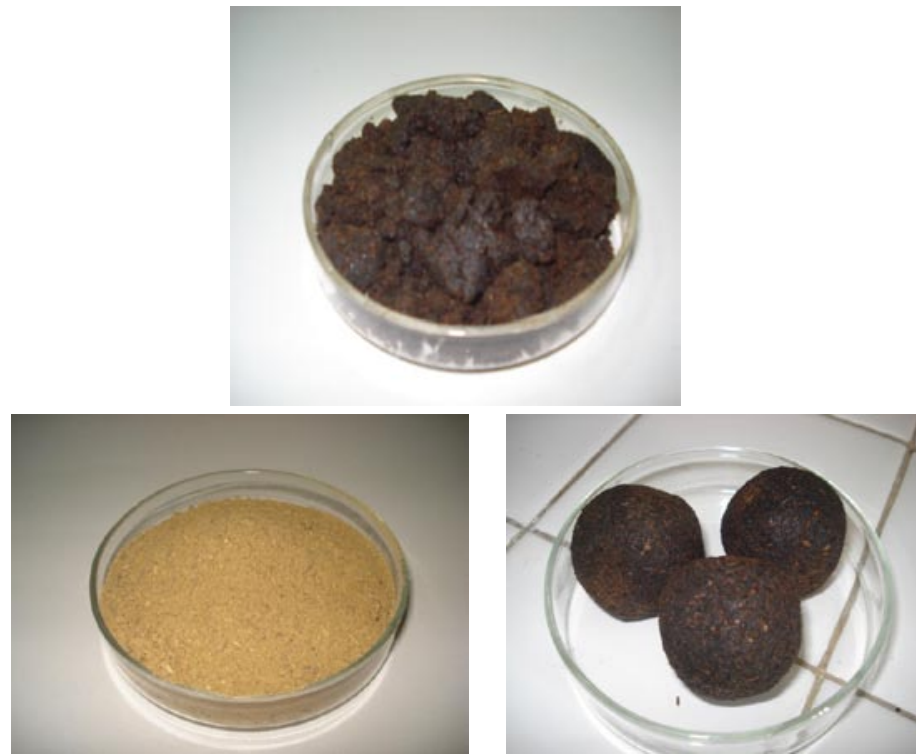

Gambar 3. Jenis-jenis ratus

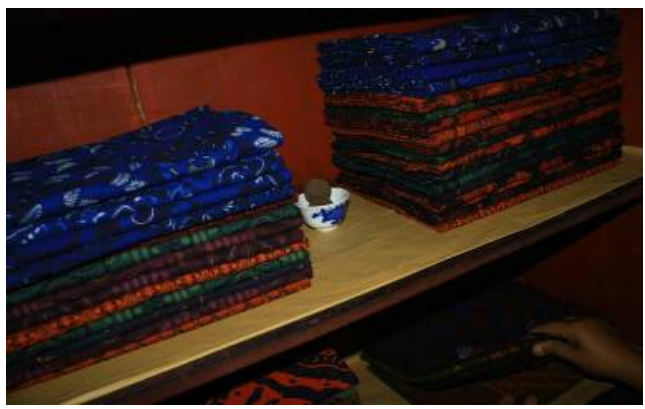

Gambar 4. Penggunaan ratus pada koleksi batik Go Tik Swan

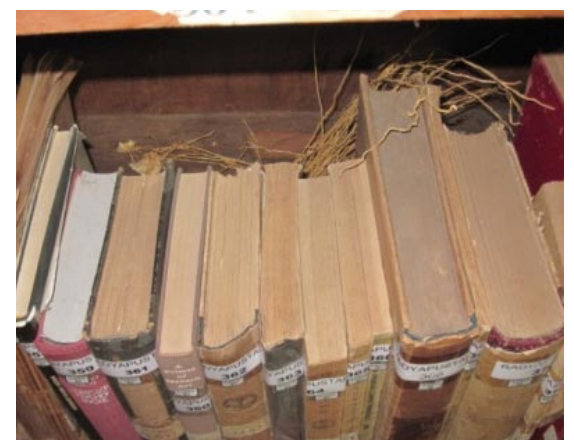

Gambar 5. Penggunaan akar wangi pada Museum Radya Pustaka serangkaian penelitian. Penelitian tersebut dilakukan melalui survei dan wawancara untuk menginventaris alat, bahan dan prosedur yang digunakan analisis laboratorium serta eksperimen.

Beberapa metode konservasi tradisional yang masih berlangsung sampai saat ini adalah penggunaan akar wangi Museum Radya Pustaka untuk melindungi koleksi buku kuno dari serangan serangga, penggunaan ratus pada koleksi batik Go Tik Swan untuk melindungi kain dari serangan ngengat dan penggunaan ekstrak cengkeh untuk mengkonservasi bangunan kayu pada rumah tradisional Kudus.

\section{B. Maksud dan Tujuan}

Maksud dari kegiatan ini adalah menyusun prosedur penelitian untuk menguji metode konservasi tradisional. Tujuan dari kegiatan penelitian adalah memperoleh informasi tentang zat aktif yang ada dalam ekstrak akar wangi dan kemampuan ekstrak akar wangi, daun cengkeh dan ratus sebagai anti jamur dan anti serangga.

\section{Metode Penelitian}

Metode penelitian dalam kegiatan ini adalah analisis laboratorium dan eksperimen atau percobaan yang dilaksanakan di Laboratorium Conservation Science NRICH. Analisis laboratorium yang dilaksanakan adalah identifikasi bahan aktif pada akar wangi, sedangkan eksperimen yang dilaksanakan meliputi tes anti jamur dan tes anti serangga pada ektrak akar wangi, ratus dan daun cengkeh.

\section{HASIL DAN PEMBAHASAN}

\section{A. Identifikasi Bahan Aktif pada Ekstrak Tanaman}

Secara prinsip untuk melakukan identifikasi zat aktif pada ekstrak tanaman didahului oleh proses persipan untuk mendapatkan partisi dan fraksi yang dilanjutkan dengan analisis kromatografi dan diakhiri dengan analisis menggunakan Nuclear Magnetic Resonance (NMR). Dalam penelitian ini dilakukan ekstraksi terhadap akar wangi dan dilanjutkan dengan analisis kromatografi, tetapi karena keterbatasan waktu dan NRICH tidak memiliki alat NMR maka penelitian tidak dilanjutkan sampai pada tahap identifikasi molekuler. Adapun urutan dan hasil analisis 
kandungan zat aktif dalam ekstrak akar wangi terdapat pada Tabel 1.

Tabel 1. Prosedur Identifikasi Bahan Aktif Dalam Ekstrak Akar Wangi

\begin{tabular}{|c|c|c|c|c|c|c|}
\hline No & Proses & Sampel & Pelarut & Fasa gerak (eluen) & Fasa diam/absorben & Hasil \\
\hline 1 & Ektraksi (extraction) & Akar wangi kering & $\mathrm{MeOH} /$ metanol $(100 \%)$ & & & $\begin{array}{l}\text { akar wangi direndam } \\
\text { dalam metanol ( } \mathrm{MeOH})\end{array}$ \\
\hline 2 & Penyaringan (filtration) & akar wangi $+\mathrm{MeOH}$ & & & & Fitrat \\
\hline 3 & $\begin{array}{l}\text { Pengumpulan (concentration) } \\
\text { Penguapan } \mathrm{MeOH} \text { dari filtrate }\end{array}$ & filtrat & & & & ekstrak akar wangi \\
\hline 4 & $\begin{array}{l}\text { Kromatografi kolom (Column } \\
\text { Chromatography /CC) } \\
\text { Hanya untuk praktek }\end{array}$ & $\begin{array}{l}\text { MLN ( sampel dari } \\
\text { laboratorium NRICH) }\end{array}$ & & $\begin{array}{l}\text { diklorometan + } \mathrm{MeOH} \text { dalam } \\
\text { perbandingan: } \\
\text { 1. } 50: 1 \\
\text { 2. } 20: 1 \\
\text { 3. } 10: 1 \\
\text { 4. } 5: 1 \\
\text { 5. } 1: 1\end{array}$ & Silica gel 60 & $\begin{array}{l}\text { 1. fraksi MLN dalam } \\
\text { perbandingan } 50: 1 \\
\text { 2. fraksi } M L N \text { dalam } \\
\text { perbandingan } 20: 1 \\
\text { 3. fraksi } M L N \text { dalam } \\
\text { perbandingan } 10: 1 \\
\text { 4. fraksi } M L N \text { dalam } \\
\text { perbandingan } 5: 1 \\
\text { 5. fraksi } M L N \text { dalam } \\
\text { perbandingan } 1: 1\end{array}$ \\
\hline 5 & $\begin{array}{l}\text { Pemisahan (fraction) } \\
\text { Untuk memisahkan ektrak akar } \\
\text { wangi extract dalam larutan heksan, } \\
\text { diklorometan dan etil asetat }\end{array}$ & $\begin{array}{l}\text { ektraf akar wangi } \\
\text { + air (100 ml) }\end{array}$ & $\begin{array}{l}\text { 1. heksan }(100 \mathrm{ml}) \times 3 \\
\text { 2. diklorometan }(100 \mathrm{ml}) \times 3 \\
\text { 3. etil asetat }(100 \mathrm{ml}) \times 3\end{array}$ & & & $\begin{array}{l}\text { 1. fraksi heksan } \\
\text { 2. fraksi diklorometan } \\
\text { 3. fraksi etil asetat } \\
\text { 4. fraksi air }\end{array}$ \\
\hline 6 & $\begin{array}{l}\text { Kromatografi Lapis Tipis (Thin Layer } \\
\text { Chromatography/TLC) } \\
\text { - Untuk mengetahui gradien } \\
\text { kelarutan setiap fraksi } \\
\text { - Untuk memilih rasio pelarut yang } \\
\text { akan digunakan untuk analisis } \\
\text { MPLC }\end{array}$ & $\begin{array}{l}\text { 1. fraksi heksan ( } 1 \mathrm{ml}) \\
\text { 2. fraksi diklorometan } \\
(1 \mathrm{ml}) \\
\text { 3. fraksi etil asetat (1 } \\
\text { ml) }\end{array}$ & $\begin{array}{l}\text { Diklorometan + } \mathrm{MeOH} \\
1: 1 \quad(300 \mu \mathrm{ll})\end{array}$ & $\begin{array}{l}\text { diklorometan }+\mathrm{MeOH} \\
\text { dengan perbandingan } \\
50: 1 \quad(2 \mathrm{ml}: 40 \mu \mathrm{l}) \\
20: 1 \quad(2 \mathrm{ml}: 100 \mu \mathrm{l}) \\
10: 1 \quad(2 \mathrm{ml}: 200 \mu \mathrm{l}) \\
5: 1 \quad(2 \mathrm{ml}: 400 \mu \mathrm{ll}) \\
1: 1 \quad(1 \mathrm{ml}: 1 \mathrm{ml})\end{array}$ & TLC plate or silica plate & $\begin{array}{l}\text { fraksi diklorometan } \\
\text { memiliki gradian kelarutan } \\
\text { yang baik pada in TLC } \\
\text { plate. Posisi sampel } \\
\text { ditengah pada rasioo 10:1 }\end{array}$ \\
\hline 7 & $\begin{array}{l}\text { Penguapan pelarut (evaporation of } \\
\text { solvent) } \\
\text { 1. untuk menguapkan heksan } \\
\text { 2. untuk menguapkan diklorometan } \\
\text { 3. untuk menguapkan etil asetat }\end{array}$ & $\begin{array}{l}\text { 1. fraksi heksan } \\
\text { 2. fraksi diklorometan } \\
\text { 3. fraksi etil asetat + } \\
\text { fraksi air }\end{array}$ & & & & $\begin{array}{l}\text { 1. Sampel H } \\
\text { 2. Sampel D } \\
\text { 3. Sampel E }\end{array}$ \\
\hline 8 & $\begin{array}{l}\text { Kromatografi Cair Bertekanan } \\
\text { Sedang (Medium Pressure Liquid } \\
\text { Chromatography/MPLC) } \\
\text { Untuk memisahkan sampel H }\end{array}$ & $\begin{array}{l}\text { Sampel H (dari fraksi } \\
\text { heksan) }\end{array}$ & $\begin{array}{l}\text { diklorometan }+\mathrm{MeOH} \\
10: 1(4 \mathrm{ml}: 400 \mu \mathrm{l})\end{array}$ & $\begin{array}{l}\text { diklorometan }+\mathrm{MeOH} \\
10: 1 \\
(2000 \mathrm{ml}: 200 \mathrm{ml})\end{array}$ & $\begin{array}{l}\text { Silica } 40-60 \mu \mathrm{m} 15 \mathrm{~g} \\
\text { volume kolom }=27 \mathrm{ml}\end{array}$ & $\begin{array}{l}\text { 1. Sampel } 1 \\
\text { 2. Sampel } 2 \\
\text { 3. Sampel } 3\end{array}$ \\
\hline 9 & $\begin{array}{l}\text { Kromatografi Lapis Tipis (Thin Layer } \\
\text { Chromatography /TLC) } \\
\text { Untuk memilih rasio pelarut untuk } \\
\text { TLC berikutnya (big silica plate) }\end{array}$ & $\begin{array}{l}\text { 1. Sampel } 1(100 \mu \mathrm{l}) \\
\text { 2. Sampel } 2(100 \mu \mathrm{ll}) \\
\text { 3. Sampel } 3(100 \mu \mathrm{l})\end{array}$ & diklorometan $(100 \mu l)$ & $\begin{array}{l}\text { diklorometan + MeOH } \\
50: 1 \quad(2 \mathrm{ml}: 40 \mu \mathrm{ll}) \\
20: 1 \quad(2 \mathrm{ml}: 100 \mu \mathrm{ll}) \\
10: 1 \quad(2 \mathrm{ml}: 200 \mu \mathrm{ll}) \\
5: 1 \quad(2 \mathrm{ml}: 400 \mu \mathrm{ll}) \\
1: 1 \quad(1 \mathrm{ml}: 1 \mathrm{ml})\end{array}$ & Silica plate (TLC plate) & $\begin{array}{l}\text { Sampele2 memiliki } \\
\text { gradien kelarutan yang } \\
\text { baik pada in TLC plate. } \\
\text { Posisi sampel ditengah } \\
\text { pada rasio } 20: 1\end{array}$ \\
\hline 10 & $\begin{array}{l}\text { Preparasi Kromatografi Lapis Tipis } \\
\text { (Prep-TLC Thin Layer } \\
\text { Chromatography) } \\
\text { Untuk memisahkan sampel } 1\end{array}$ & sampel $1(500 \mu \mathrm{l})$ & metil klorida $(500 \mu l)$ & $\begin{array}{l}\text { diklorometan }+\mathrm{MeOH} \\
20: 1(100 \mathrm{ml}: 5 \mathrm{ml})\end{array}$ & $\begin{array}{l}\text { Silica gel } 60 \mathrm{~F} 254 \\
\text { Plate ukuran } 20 \times 20 \mathrm{~cm}\end{array}$ & $\begin{array}{l}\text { 1. silica gel } 1 \text { (hexane F) } \\
\text { 2. silica gel } 2 \text { (hexane F) } \\
\text { 3. silica gel } 3 \text { (hexane F) } \\
\text { 4. silica gel } 4 \text { (hexane F) }\end{array}$ \\
\hline 11 & $\begin{array}{l}\text { Kromatografi Kolom LH-20 (LH-20 } \\
\text { Column Chromatography) } \\
\text { Untuk memisahkan sapel pada silica } \\
\text { gel 1(dari fraksi heksan) }\end{array}$ & silica gel 1 (heksan F) & $\begin{array}{l}\text { diklorometan }+\mathrm{MeOH} \\
1: 1\end{array}$ & $\begin{array}{l}\text { diklorometan }+\mathrm{MeOH} \\
1: 1\end{array}$ & Sephandex TM LH-20 & $\begin{array}{l}\text { Fraksi } 1 \text { sampai dengan } \\
\text { fraksi } 50\end{array}$ \\
\hline 12 & $\begin{array}{l}\text { Kromatografi Lapis Tipis (Thin Layer } \\
\text { Chromatography/TLC) } \\
\text { Untuk memilih fraksi yang berisi } \\
\text { material untuk analisis HPLC }\end{array}$ & fraksi $2,4,6 \ldots .50$ & $\begin{array}{l}\text { Diklorometan }+\mathrm{MeOH} \\
\text { 1:1 }(100 \mu \mathrm{l})\end{array}$ & 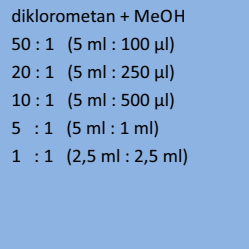 & silica plate (TLC plate) & $\begin{array}{l}\text { Ada wana pelangi pada } \\
\text { fraksi nomer } 10 \text { dalam } \\
\text { pelarut dengan rasio } 50.1 \\
\text { sehingga material } \\
\text { kemungkinan berada pada } \\
\text { fraksi nomer } 9,10 \text { dan } 11 . \\
\text { Dilanjutkan menggunakan } \\
\text { rasio pelarut } 20.1 \text { dan } \\
\text { ditemukan material pada } \\
\text { fraksi nomer } 10\end{array}$ \\
\hline 13 & $\begin{array}{l}\text { Kromatografi Cair Bertekanan } \\
\text { Tinggi (High Pressure Liquid } \\
\text { Chromatography /HPLC) } \\
\text { Untuk pemisahan fraksi nomor } 10\end{array}$ & 1. fraksi nomer 10 & $\mathrm{MeOH}$ & $\begin{array}{l}\mathrm{MeOH}+\text { air } \\
100 \%: 0 \% \\
90 \%: 10 \% \\
80 \%: 20 \% \\
70 \%: 30 \% \\
60 \%: 40 \%\end{array}$ & $\begin{array}{l}\text { X Select CSH TM C18 } 3.5 \\
2.1 \times 100 \text { mm column }\end{array}$ & $\begin{array}{l}\text { Hasil yang baik dalam } \\
\text { pelarut } \mathrm{MeOH} 80 \% \text {, } \\
\text { ret.time } 9.783 \text { pada } \\
\text { daerah } 203881 \text {, tinggi } \\
\text { kurva } 3870 .\end{array}$ \\
\hline 14 & $\begin{array}{l}\text { NMR (nuclear magnification } \\
\text { resonance) } \\
\text { Untuk identifikasi molekul }\end{array}$ & & & & & Tidak dilaksanakan \\
\hline
\end{tabular}




\section{B. Tes Anti Jamur}

Tes anti jamur dilakukan untuk mengetahui daya hambat ekstrak akar wangi, daun cengkeh, ratus dan metanol terhadap pertumbuhan jamur perusak material cagar budaya berbahan organik. Sampel yang diuji kemampuanya dalam menghambat pertumbuhan jamur sebagai berikut :

1. Ekstrak akar wangi (kode A)

2. Ekstrak daun cengkeh (kode D)

3. Ektstrak ratus (kode R)

4. Metanol (kode $\mathrm{MeOH}$ )

5. Tanpa perlakuan sebagai kontrol (kode C)

Konsentrasi ekstrak tersebut 1\%, 5\%, 10\% dan 20\% yang dilarutkan pada metanol $(\mathrm{MeOH})$.
Jenis-jenis jamur yang digunakan sebagai jamur uji adalah jenis mold dan rot fungi (tabel 2).

\section{a) Hasil Tes Anti Jamur terhadap Mold}

Hasil tes anti jamur ekstrak akar wangi, daun cengkeh dan ratus terhadap mold digambarkan dalam area penghambatan terhadap mold, yang dihitung berdasarkan diameter dari luas penghambatan. Hasil pengukuran area penghambatan ekstrak tanaman terhadap pertumbuhan mold terdapat pada Tabel 3.

Berdasarkan tabel tersebut di atas diketahui bahwa ekstrak daun cengkeh menunjukan area penghambatan tertinggi terhadap pertumbuhan mold dan berikutnya ekstrak ratus. Ekstrak akar wangi dan metanol tidak menunjukan adanya area penghambatan.

Tabel 2. Jenis-Jenis Jamur Uji

\begin{tabular}{cll} 
Jenis Jamur & \multicolumn{1}{c}{ Kode } & \multicolumn{1}{c}{$\begin{array}{c}\text { Nama Spesies } \\
\text { Mold }\end{array}$} \\
H.1 & Cladosporium sp. \\
ola E-3 & Pleosporales sp. \\
ola E-6 & Penicilium griseofuluum \\
& ola E-10 & Penicilium sp. \\
Root Fungi & ola E-n & Hypoxyion sp. \\
& ola E-11 & Daldinia sp. \\
\hline
\end{tabular}

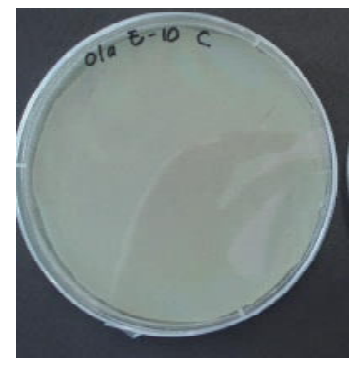

Ola E-10 C

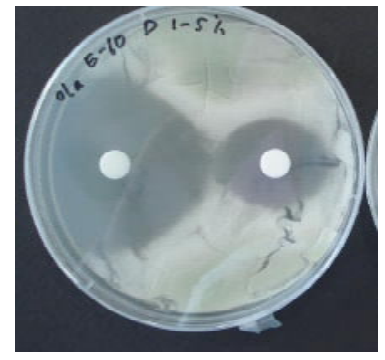

Ola E-10 D 1-5\%

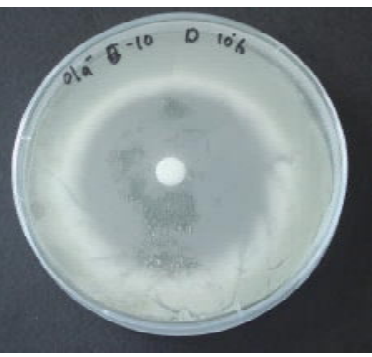

Ola E-10 D 10\%

Tabel 3. Area Penghambatan Ekstrak Tanaman Terhadap Pertumbuhan Mold

\begin{tabular}{|c|c|c|c|c|c|c|c|c|c|c|c|c|c|}
\hline \multirow{2}{*}{\multicolumn{2}{|c|}{ Extract }} & \multicolumn{3}{|c|}{ ola E-3 (M) } & \multicolumn{3}{|c|}{ ola E-6 (M) } & \multicolumn{3}{|c|}{ ola E-10 (M) } & \multicolumn{3}{|c|}{ H-1 (M) } \\
\hline & & \multirow{2}{*}{$\begin{array}{l}1 \\
0\end{array}$} & \multirow{2}{*}{$\begin{array}{l}2 \\
0\end{array}$} & \multirow{2}{*}{$\begin{array}{c}\text { rerata } \\
0\end{array}$} & \multirow{2}{*}{$\begin{array}{l}1 \\
0\end{array}$} & \multirow{2}{*}{$\begin{array}{l}2 \\
0\end{array}$} & \multirow{2}{*}{$\begin{array}{c}\text { rerata } \\
0\end{array}$} & \multirow{2}{*}{$\begin{array}{l}1 \\
0\end{array}$} & \multirow{2}{*}{$\begin{array}{l}2 \\
0\end{array}$} & \multirow{2}{*}{$\begin{array}{c}\text { rerata } \\
0\end{array}$} & \multirow{2}{*}{$\begin{array}{l}1 \\
-\end{array}$} & \multirow{2}{*}{$\begin{array}{r}2 \\
-\end{array}$} & \multirow[t]{2}{*}{ rerata } \\
\hline A & $1 \%$ & & & & & & & & & & & & \\
\hline & $5 \%$ & 0 & 0 & 0 & 0 & 0 & 0 & 0 & 0 & 0 & - & - & \\
\hline & $10 \%$ & 0 & 0 & 0 & 0 & 0 & 0 & 0 & 0 & 0 & - & - & \\
\hline & $20 \%$ & 0 & - & 0 & 0 & - & 0 & 0 & - & 0 & 0 & - & 0 \\
\hline \multirow[t]{4}{*}{ D } & $1 \%$ & 0 & 0 & 0 & 0 & 77 & 38,5 & 25 & 30 & 27,5 & - & - & \\
\hline & $5 \%$ & 17 & 16 & 16,5 & 35 & 35 & 35 & 48 & 45 & 46,5 & - & - & \\
\hline & $10 \%$ & 85 & 85 & 85 & 30 & 25 & 27,5 & 55 & 50 & 52,5 & - & - & \\
\hline & $20 \%$ & 85 & - & 85 & 25 & - & 25 & 45 & - & 45 & 30 & - & 30 \\
\hline \multirow[t]{4}{*}{$\mathrm{R}$} & $1 \%$ & 0 & 0 & 0 & 0 & 0 & 0 & 0 & 0 & 0 & - & - & \\
\hline & $5 \%$ & 0 & 0 & 0 & 0 & 12 & 6 & 0 & 0 & 0 & - & - & \\
\hline & $10 \%$ & 0 & 0 & 0 & 15 & 0 & 7,5 & 20 & 20 & 20 & - & - & \\
\hline & $20 \%$ & 20 & - & 20 & 20 & - & 20 & 20 & - & 20 & 0 & - & 0 \\
\hline \multicolumn{2}{|c|}{$\mathrm{MeOH}$} & 0 & 0 & 0 & 0 & 0 & 0 & 0 & 0 & 0 & - & - & - \\
\hline \multicolumn{2}{|c|}{ Control } & 0 & 0 & 0 & 0 & 0 & 0 & 0 & 0 & 0 & - & - & - \\
\hline
\end{tabular}

\section{Keterangan :}

A

$\mathrm{D}$

$\mathrm{R}$

Ola E-3

Ola E-6

Ola E-10

$\mathrm{H}-1$

$\mathrm{C}$

0

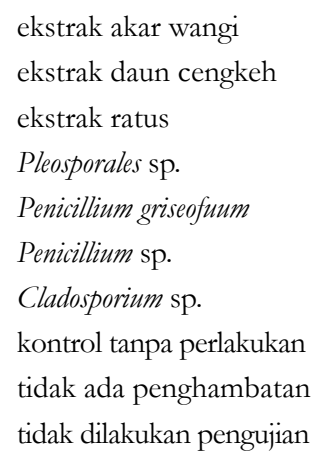




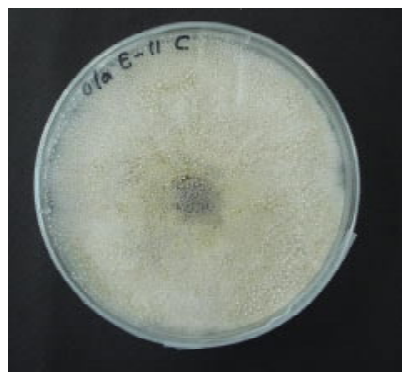

Ola E-11 C

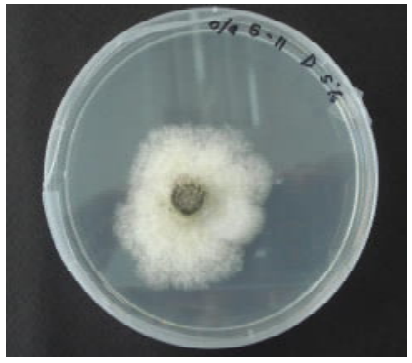

Ola E-11 D 5\%

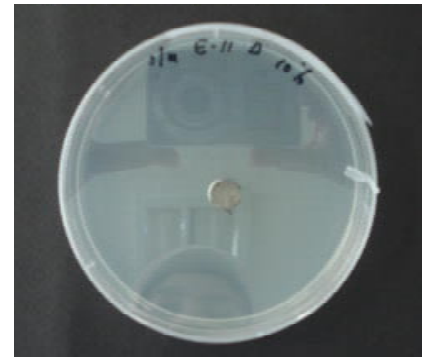

Ola E-11 D $10 \%$

Tabel 4. Rasio Penghambatan Ekstrak Tanaman Terhadap Pertumbuhan Rot Fungi

\begin{tabular}{|c|c|c|c|c|c|c|c|c|c|c|c|}
\hline \multirow{2}{*}{\multicolumn{2}{|c|}{ Extract }} & \multicolumn{4}{|c|}{ ola E-11 (RF) } & \multicolumn{4}{|c|}{$\cdots$} & \multicolumn{2}{|c|}{ Keterangan : } \\
\hline & & 1 & 2 & rerata & IR & 1 & 2 & rerata & IR & & : Hypoxylon \\
\hline \multirow[t]{4}{*}{ A } & $1 \%$ & 85 & 85 & 85 & 0,00 & 75 & 75 & 75 & 11,76 & IR & - Inhibition Ratio \\
\hline & $5 \%$ & 85 & 85 & 85 & 0,00 & 70 & 65 & 67,5 & 20,59 & & $(\%)$ \\
\hline & $10 \%$ & 75 & 85 & 80 & 5,88 & 62 & 60 & 61 & 28,24 & 0 & : tidak ada \\
\hline & $20 \%$ & 85 & - & 85 & 0,00 & 67 & - & 67 & 21,18 & & pertumbuhan \\
\hline \multirow[t]{4}{*}{$\mathrm{D}$} & $1 \%$ & 85 & 85 & 85 & 0,00 & 70 & 80 & 75 & 11,76 & - & : tidak dilakukan \\
\hline & $5 \%$ & 75 & 40 & 57,5 & 32,35 & 60 & 45 & 52,5 & 38,24 & & pengujian \\
\hline & $10 \%$ & 16 & 0 & 8 & 90,59 & 20 & 0 & 10 & 88,24 & & \\
\hline & $20 \%$ & 0 & - & 0 & 100,00 & 0 & - & 0 & 100,00 & & \\
\hline \multirow[t]{3}{*}{$\mathrm{R}$} & $1 \%$ & 82 & 85 & 83,5 & 1,76 & 80 & 80 & 80 & 5,88 & & \\
\hline & $10 \%$ & 70 & 70 & 70 & 17,65 & 55 & 60 & 57,5 & 32,35 & & \\
\hline & $20 \%$ & 65 & - & 65 & 23,53 & 50 & - & 50 & 41,18 & & \\
\hline \multicolumn{2}{|c|}{$\mathrm{MeOH}$} & 85 & 85 & 85 & 0,00 & 80 & 75 & 77,5 & 8,82 & & \\
\hline \multicolumn{2}{|c|}{ Control (C) } & 85 & 85 & 85 & 0,00 & 85 & 85 & 85 & 0,00 & & \\
\hline
\end{tabular}

\section{b) Hasil Tes Anti Jamur terhadap Rot Fungi}

Hasil tes anti jamur ekstrak akar wangi, daun cengkeh dan ratus terhadap rot fungi digambarkan dalam area penghambatan terhadap rot fungi yang dihitung berdasarkan rasio penghambatan dengan rumus sebagai berikut:

$$
\operatorname{IR}(\%)=\underline{\mathrm{A}-\mathrm{B}} \times 100 \%
$$$$
\text { A }
$$$$
\text { IR : rasio penghambatan (\%) }
$$$$
\text { A : diameter pertumbuhan hifa kontrol }
$$$$
\text { B : diameter pertumbuhan hifa perlakukan }
$$

Berdasarkan hasil perhitungan rasio penghambatan diketahui bahwa ekstrak daun cengkeh menunjukan hasil terbaik dalam mengambat pertumbuhan rot fungi, kedua ratus dan ketiga akar wangi. Metanol menunjukan area penghambatan paling rendah.

\section{Tes Anti Serangga}

Dalam tes anti serangga terhadap ekstrak akar wangi, daun cengkeh dan ratus mengunakan serangga uji Cigarette beetle. Cigarette beetle merupakan serangga yang sangat umum digunakan sebagai serangga uji dalam tes anti serangga. Sampel yang diuji kemampuanya dalam tes anti serangga sebagai berikut:
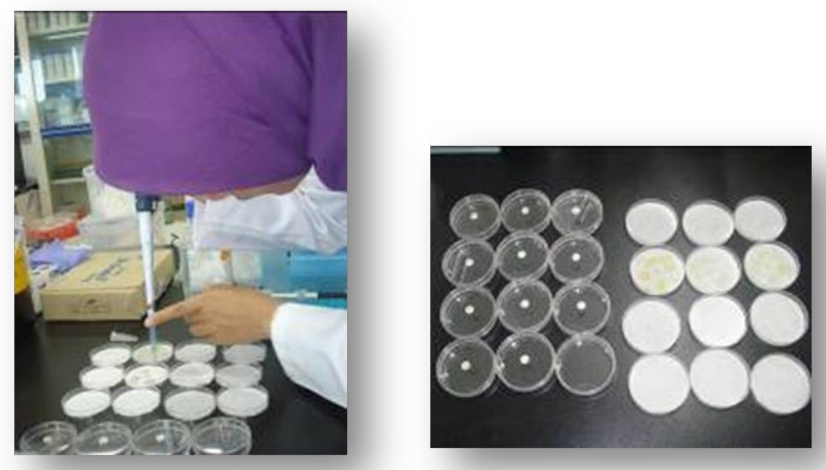

Gambar 6. Tes Anti Serangga Ekstrak Akar Wangi, Ratus dan Daun Cengkeh terhadap Cigarette beetle. 

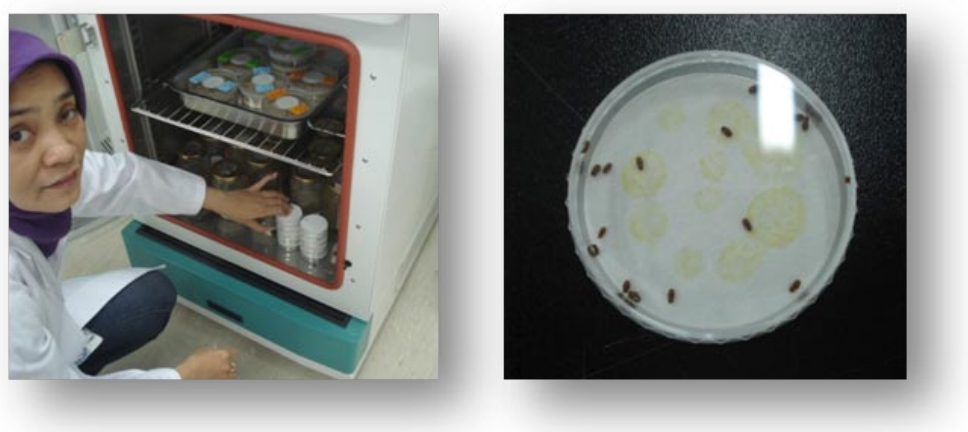

Gambar 6. Tes Anti Serangga Ekstrak Akar Wangi, Ratus dan Daun Cengkeh terhadap Cigarette beetle.

Tabel 5. Hasil Observasi Tingkat Kematian Cigarette beetle setelah 48 Jam

\begin{tabular}{|c|c|c|c|c|c|}
\hline Perlakukan & Ulangan & $\begin{array}{l}\text { Jumlah Cigarette } \\
\text { beetle yang mati }\end{array}$ & Jumlah & Rata-rata & Kematian (\%) \\
\hline \multirow{3}{*}{ A } & 1 & 2 & \multirow{3}{*}{5,00} & \multirow{3}{*}{1,67} & \multirow{3}{*}{8,33} \\
\hline & 2 & 0 & & & \\
\hline & 3 & 3 & & & \\
\hline \multirow{3}{*}{ D } & 1 & 2 & \multirow{3}{*}{21,00} & \multirow{3}{*}{7,00} & \multirow{3}{*}{35,00} \\
\hline & 2 & 5 & & & \\
\hline & 3 & 14 & & & \\
\hline \multirow{3}{*}{$\mathrm{R}$} & 1 & 4 & \multirow{3}{*}{9,00} & \multirow{3}{*}{3,00} & \multirow{3}{*}{15,00} \\
\hline & 2 & 1 & & & \\
\hline & 3 & 4 & & & \\
\hline \multirow{3}{*}{ C } & 1 & 3 & \multirow{3}{*}{3,00} & \multirow{3}{*}{1,00} & \multirow{3}{*}{5,00} \\
\hline & 2 & 0 & & & \\
\hline & 3 & 0 & & & \\
\hline
\end{tabular}

\section{Keterangan:}

A : akar wangi extract

D : daun cengkeh extract

R : ratus extract

C : control / ethanol $70 \%$
1. Ekstrak akar wangi (A)

2. Ekstrak daun cengkeh (D)

3. Ekstrak ratus (R)

4. Methanol sebagai kontrol (C)

Konsentrasi: $0,05 \mathrm{~g} / \mathrm{ml}$ dalam etanol

Volume : $300 \mu \mathrm{l}$

Berdasarkan hasil observasi jumlah Cigarette beetle yang mati dalam setiap perlakuan selama 48 jam disajikan dalam Tabel 5.

Berdasarkan hasil perhitungan dalam Tabel 5. diketahui bahwa ekstrak daun cengkeh menyebabkan kematian tertinggi pada Cigarette beetle dengan rata-rata kematian 35\% setelah waktu paparan 48 jam. Perlakukan ekstrak ratus menyebabkan kematian Cigarette beetle 15\% dan ekstrak akar wangi 8,33\% sedangkan etanol hanya menyebabkan kematian serangga uji sebanyak 5\%. Uji ekstrak daun cengkeh dan ratus menunjukan hasil yang baik karena dosis dan volume ekstrak yang digunakan masih terbilang sangat rendah.

\section{KESIMPULAN DAN SARAN}

\section{A. Kesimpulan:}

1. Prosedur dalam identifikasi zat aktif dari ekstrak tanaman secara berurutan sebagai berikut: ekstraksi, filtrasi atau penyaringan, pengumpulan (concentration), pemisahan (fraksi), analisis kromatografi dan nuclear magnetic resonance.

2. Dalam penelitian ini belum dapat diidentifikasi zat aktif yang terdapat dalam ekstrak akar wangi.

3. Ekstrak daun cengkeh menunjukan area penghambatan tertinggi terhadap pertumbuhan mold dan berikutnya ekstrak ratus. Ekstrak akar wangi dan metanol tidak menunjukan adanya area penghambatan terhadap pertumbuhan mold.

4. Ekstrak daun cengkeh menunjukan hasil terbaik dalam menghambat pertumbuhan rot fungi, kedua ratus dan ketiga akar wangi. Metanol menunjukan area penghambatan paling rendah.

5. Ekstrak daun cengkeh menyebabkan kematian tertinggi pada Cigarette beetle dengan rata-rata kematian 
35\% setelah waktu paparan 48 jam.

\section{B. Saran:}

1. Penelitian seharusnya dilanjutkan untuk mengetahui zat aktif yang ada dalam ekstrak akar wangi, daun cengkeh dan ratus.

2. Penelitian anti-jamur dan anti-serangga seharusnya dilanjutkan dengan meningkatkan konsentrasi atau dosis lebih tinggi.

\section{DATAR PUSTAKA}

Ayer, Sloan etc. 2012. Cytotoxic Xanthone-anthraquinone heterodimers from an unidentified fungus of the Order Hupocreales (MSX 17022), Japan Antibiotic Research, The Journal Antibiotics 65, 3-8.

Beek, Teris. 1999. Modern Methods of Secondary Product Isolation and Analysis. Chemical from Pants Perspectives on Plant Secondary Products. NJ. Walton and DE. Brown. Imperial College, London. Page $91-186$

Harborne, J.B. 1999. Classes and Functions of Secondary Product from Plants. Chemical from Pants Perspectives on Plant Secondary Products. NJ. Walton and DE. Brown. Imperial College, London. 1-25

Izumikawa, Miho, etc. 2012. A New Cyclizidine Analog - JBIR-102- from Saccharopolyspora sp. RL78 Isolated from Mangrove Soil. Japan Antibiotic Research Association. The Journal Antibiotics $65,41-43$

Kawahara, T etc. 2012. JBIR-124: a Novel Antioxidative Agent from a Marine Sponge-derived Fungus Penicilliu citrium sp108062G1f01. Japan Antibiotic Research. The Journal Antibiotics 65, 45-47.

Kim, Young-Hee. 2012. Application and Utilization of Plant Extracts for Pest Control on Biological Conservation. Textbook Vol. 1. General Lectures of Asia Cooperation Program on Conservation Science. Conservation Science Division. National Research Institute of Cultural Heritage, Korea
3. Serangga yang digunakan sebagai serangga uji sebaiknya jenis serangga yang umum menyerang material cagar budaya.

McKay P. 2010. An Introduction to Chromatography http://en.wikipedia.org/wiki/kromatografi) (26 August 2012)

Saker, Satyajit. 1999. Methods in Biotechnology: Natural Products Isolation. Humana Press. Totowa, New Jersey.

Striegel, Mary and Hill, Jo. 1997. Thin Layer Chromatography: Scientific Tools for Conservation. The Getty Conservation Institute, USA

Tissue BM. 2000. Chromatography. (http://id.wikipedia. org/wiki/Kromatografi) (26 August 2012)

Umeda, Yukiko etc. 2005. Prunustatin A, a Novel GRP78 Molecular Chaperone Down-regular Isolated from Steptomyces violaceoniger. Japan Antibiotic Research The Journal Antibiotics 58(3), 206209

Walton, NJ, etc. 1999. Characterisation and Control of Plant Secondary Methabolism. Chemical from Pants Perspectives on Plant Secondary Products. NJ. Walton and DE. Brown. Imperial College, London. 27 -90

http: / / en.wikipedia.org/wiki/Thin_layer_ chromatography (23 August 2012) 